\title{
Ethiek tussen alliantie en dissidentie
}

Citation for published version (APA):

ten Have, H. (1990). Ethiek tussen alliantie en dissidentie. Rijksuniversiteit Limburg. https://doi.org/10.26481/spe.19900209hh

Document status and date:

Published: 09/02/1990

DOI:

10.26481/spe.19900209hh

Document Version:

Publisher's PDF, also known as Version of record

\section{Please check the document version of this publication:}

- A submitted manuscript is the version of the article upon submission and before peer-review. There can be important differences between the submitted version and the official published version of record.

People interested in the research are advised to contact the author for the final version of the publication, or visit the DOI to the publisher's website.

- The final author version and the galley proof are versions of the publication after peer review.

- The final published version features the final layout of the paper including the volume, issue and page numbers.

Link to publication

\footnotetext{
General rights rights.

- You may freely distribute the URL identifying the publication in the public portal. please follow below link for the End User Agreement:

www.umlib.nl/taverne-license

Take down policy

If you believe that this document breaches copyright please contact us at:

repository@maastrichtuniversity.nl

providing details and we will investigate your claim.
}

Copyright and moral rights for the publications made accessible in the public portal are retained by the authors and/or other copyright owners and it is a condition of accessing publications that users recognise and abide by the legal requirements associated with these

- Users may download and print one copy of any publication from the public portal for the purpose of private study or research.

- You may not further distribute the material or use it for any profit-making activity or commercial gain

If the publication is distributed under the terms of Article $25 \mathrm{fa}$ of the Dutch Copyright Act, indicated by the "Taverne" license above, 


\title{
ETHIEK TUSSEN ALLIANTIE EN DISSIDENTIE
}

\author{
Rede
}

uitgesproken bij de aanvarding van het ambt van bijzonder hoogleraar vanwege de

RadboudstichtingWetenschappelijkOnderwijsfonds in de wijsbegeerte in betrekking tot de katholieke levensbeschouwing aan de Rijksuniversiteit Limburg op vrijdag 9 februari 1990 door

dr Henk ten Have 
Van deze rede zal een uitgebreide versie in boekworm werschijnen bij uitgeverij De Tijdstroom te Lochem in september 1990.

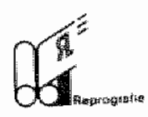


Mijnheer de rector magnificus,

\section{Geachte toehoorders,}

Beter laat dan nooit. Dat geldt woor deze oratie. Het is ook een hartekreet wan de Amerikaanse ethicus en jezuiet Richard McCormick aan hel adres van de katholieke moraaltheologie. Die theologie komt al maar minder toe aan haar bemiddelende rol tussen evangelische waarden en eigentijdse samenleving. Het spelen van die rol wordt haar bemoeilijkt door de eigen kerk, nu daarin steeds vaker wordt uitgegaan van een tegenstelling tussen moderne wereld en kerkelijk leergezag. McCormick spreekt wat dit betreft van"reconstructionisme". ${ }^{1}$ Alweer een kwart eeuw geleden had het Tweede Vaticaans Concilie de kerk gesitueerd temidden van de wereld en haar geschiedenis. Het geloofsgoed dat aan de kerk is toevertrouwd, moet immers in de wereld zelf verwerkelijkt worden. Dat houdt in dat de wijze waarop het geloofsgoed wordt geïnterpreteerd, geformuleerd en verkondigd verandert. Bovendien volgt daaruit dat er niet altijd direct een oplossing voor specifieke problemen bij de hand is. Het Nieuwe Testament anticipeert niet op elk mogelijk moreel dilemma en presenteert evenmin een uitgewerkt ethisch systeem. Ambiguilteiten zijn het gevolg.

Het hedendaags reconstructionisme wil met dergelijke ambiguiteiten af rekenen. De motivatie hiertoe wordt nogal eens ontleend aan een cultuurpessimistisch perspectief dat de kerk beschouwt als aangetast door een ernstige degeneratieve ziekte die alleen met harde middelen kan worden geheeld. Op grond van deze diagnose en therapiekeuze wordt in ethische kwesties een ondubbelzinnig duidelijke stelling betrokken die vrij dient te zijn van elke ambiguïteit. Daarbij wordt niet geschroomd op allerllei kwesties vrij gedetailleerd in te gaan. Stringent wil men bepalen waar de grens ligt tussen goed en kwaad, tussen permissie en verbod. Hierdoor is een ethiek van voornamelijk absolutiva en negativa ontstaan, zodat bij velen de indruk leeft dat een katholieke levensbeschouwing niet meer te maken heeft met een blijde boodschap maar met het navolgen van achterhaalde verboden en woorschriften.

Daarmee wordt onrecht gedaan aan de eigen traditie. Die is genuanceerder, rijker en positiever dan het beeld dat er nu gewoonlijk van bestaat. Een aantal opmerkingen kan dat illustreren. De morele leer van de kerk heeft zichzelf vanouds begrepen als "parenesis", dat wil zeggen aansporing, appèl. ${ }^{2}$ Dan gaat het niet zozeer om het beslissen wat juist of onjuist is in een bepaalde situatie maar om het aanmoedigen van een wijze van han delen die het voorbeeldige leven van Jezus zoveel mogelijk benadert. Door 
ecn directe relatie te leggen tussen algemene beginselen en specifieke handelingsaanwijzingen wordt ethiek gereduceerd tot moralisme. Daarmee is verdwenen wat specifiek is voor ethiek, namelijk de combinatie van het element van beraad, overleg, afweging, met het element van appèl, inspiratie, bezieling. Bowendien valt op hoezeer in de moderne tijd, ook in levensbeschowwelijk perspectief, de nadruk is komen te liggen op vragen als "Wat moeten we doen?" of "Mag dit of dat?". Daardoor is de primaire vraag "Hoe te leven?" op de achtergrond geraakt. Die laatste vraag heeft meer te maken met een basale orientatie, een fundamentele instelling dan met regels en principes, meer ook met een coherent moreel leven dan met afzonderlijke handelingen. Tenslotte lijkt de preoccupatie met de juiste regels en principes de afstand tussen leer en praktijk te veronachtzamen en die alstand soms zelfs niet eens meer als probleem voor de leer zelf te beschouwen. Vanouds was het overbruggen van deze afstand de belangrijkste inzet van pastorale activiteiten. Die activiteiten hadden op hun beurt een weerslag op het spreken van het kerkelijk leergezag. Thans lijkt van wisselwerking weinig sprake te zijn. De eerder genoemde McCormick signaleert dit in, onder andere, het niet langer toestaan van dissidentie binnen met name de moraal theologie. ${ }^{3}$ Dissidentie zorgt voor voortdurende revisie en herformulering; daardoor kan de geloofsleer zich ontwikkelen zodat tussen leer en praktijk geen onoverbrugbare kloof ontstaat. Momenteel lijkt die functie niet meer als positief te worden gewaardeerd. Dissidentie wordt opgevat als gebrek aan loyaliteit. Daardoor degenereren morele problemen tot autoriteitsproblemen.

Deze opmerkingen zijn des te meer van toepassing als we kijken naar de relatie tussen katholieke levensbeschouwing en moderne gezondheidszorg. Gedurende haar geschiedenis heeft de rooms-katholieke kerk zich steeds beziggehouden met medische aangelegenheden. Deze interesse is zeker niet van de latatste tijd. Binnen haar traditie is er een overmaat van literatuur over medische ethiek. ${ }^{4}$ Vanaf het begin van deze eeuw ontstonden bovendien katholieke artsenorganisaties en tijdschriften met bijzondere aandacht voor medische ethick. ${ }^{5}$ op zich leidde dat niet tot een tegenstelling tussen beroepsuitoefening en religieus geïnspireerde morele opvattingen. In plaats van verboden werd immers vooral een extra positieve inspanning gevraagd, temeer ondat allerlei gezondheidszorgpraktijken (bij voorbeeld ziekenhuizen) onder katholieke hoede waren geplaatst. Die vruchtbare alliantie is drastisch weranderd.

De geneeskunde heeft zich in de westerse cultuur zodanig ontwikkeld dat ze geworden is tot een mechanisme dat existentiële ervaringen van ge- 
boorte, ziek-zijn, lijden, veroudering, en sterven omzet tot technische problemen. Vanuit levensbeschouwelijk perspectief is zinvolle kritiek te leveren, bij voorbeeld op de tendenties tot economisering en vertechnisering van menselijke relaties. Maar juist door het gebrek aan interne dissidentie binnen de katholieke moraaltheologie is een vruchtbare dissidente positie ten opzichte van de moderne geneeskunde steeds minder mogelijk.

Een goed voorbeeld wat dit betreft is de drie jaar geleden verschenen Instructie "Donum Vitae" van de Vaticaanse Congregatie voor de Geloofsleer. ${ }^{6}$ Dit document werd met enige voortvarendheid uitgebracht teneinde de discussie over moderne voortplantingstechnologie, en met name wetgeving daaromtrent, te beinvloeden. De reacties erop waren echter overwegend negatief. Dat ligt voor een deel aan vorm die het magisterieel spreken hier heeft gekozen. Ook het ethisch uitgangspunt is niet zonder bezwaar." Waar het me nu vooral om gaat is dat de negatieve respons minstens evenzeer te maken heeft met het type ethiek dat in het document tot uiting komt: namelijk deductivisme. Uit algemene principes worden concrete richtlijnen afgeleid. Kennis van specifieke kenmerken van situaties, empirische gegevens en wetenschappelijke ontwikkelingen zijn in deze optiek betrekkelijk irrelewant. De soms detaillistische preoccupatie met concrete richtlijnen leidt de aandacht weg van de meer fundamentele cultuurkritiek die ook in de Instructie Donum Vitae aanwezig is. Daardoor blijft onduidelijk waarom regels gewenst zijn en waarom juist deze regels ons moeten interesseren. Bovendien veronderstelt deductivisme een vals di lemma. Het is niet zo dat het enige alternatief bestaat in een inductivisme dat vanuit concrete situaties op zoekgaat naar bruikbare richtlijnen en daardoor gemakkelijk leidt tot een relativistische situatie-ethiek. Er is een middenweg en die is in de moraaltheologie ook lange tijd gekozen. Volgens Thomas van Aquino bij voorbeeld beperkt de natuurwet zich tot algemene beginselen; Thomas is zeer terughoudend met het nader specificeren van die beginselen. In zijn studies over de natuurwet als zedelijke norm concludeert Van Melsen dat iets soortgelijks geldt woor het recht: elke poging de inhoud van het naturrecht in extenso vast te stellen draagt te zeer eigentijdse trekken en blijkt, dientengevolge, vroeg of laat te mislukken. ${ }^{8}$ Dat betekent dat ethiek wel een algemene oriëntatie kan geven maar dat als regel niet kan worden bepaald wat in concreto goed of kwaad is zonder daarin de eigentijdse overwegingen van relevante disciplines als bij voorbeeld de geneeskunde te betrekken. Een concrete bepaling komt dus voort uit een dialoog. 
Ook op dit punt schiet de Instructic tekort. Ze leidt niet tot een dialoog omdat ze daar zelf ook miet uit is voortgekomen. Het consultatieproces heeft geen ruimte gelaten woor dissidente opvattingen. Uit wat daarvan nu bekend is, kan men afleiden dat alleen diegenen zijn geconsulteerd van wie men tevoren wist dat ze vooropgestelde conclusies onderschreven. ${ }^{9}$ Het document had aan overtügingskiracht gewonnen alls het iets had laten zien van de moeizame worsteling met medisch-ethischevraagstukken, een worsteling die velen uit de praktijk van de gezondheidzorg zouden hebben herkend.

Bovenstaande bedenkingen behouden hun relevantie als we onze aandacht verplaatsen naar de huidige situatie van de medische ethiek in het algemeen. Met andere woorden, wat ik zoëven signaleerde naar aanleiding van de katholieke moraaltheologie, geldt naar mijn mening evenzeer voor de conceptie van medische ethiek die heden ten dage in ons land domineert. Dat is op het eerste gezicht merkwaardig omdat die conceptie zichzelf inhoudelijk ge profileerd heeft in oppositie tegen christelijke geinspireerde ethiek, namelijk als expliciet seculiere benadering van medisch-ethische vraagstukken. Wat de inhoud betreft zijn er inderdaad grote verschillen, maar ik wil laten zien dat er naar de vorm opvallende overeenkomsten zijn. Ook in veel seculiere medisch-ethische literatuur wordt meer aandacht gegeven aan concrete normen en regels dan aan fundamentele thema's en algemene oriëntaties.

De medisch ethicus laat zich tegenwoordig nogal eens, soms tegen wil en dank, soms met graagte, in de positie plaatsen van iemand die de normen en regels kent, die antwoorden paraat heeft voor elk nieuw probleem en ons telkens weer door ingewikkelde dilemma's loodst.

Deze oratie is primair een pleidooi voor bescheidenheid, een pleidooi voor een meer bescheiden rol van de medisch-ethicus in het publieke debat over morele aspecten van gezondheidszorg.

\section{ETHIEK-KRITIEK}

Het nieuwe jaar werd in het Nederlands Tijdschrift woor Geneeskunde ingeluid met een commentaar waarin medische ethiek en gezondheidsrecht afgeschilderd werden als hinderpalen voor de vooruitgang van de geneeskunde. ${ }^{10}$ Beoefenaars van deze vakken, zo beweert de auteur, menen onder dekking van de grondwet en zich beroepend op de autonomie van de patient, het primaat te hebben van het juiste uitgangspunt. Medisch-ethici en gezondheidsjuristen zouden er, aldus de commentator, goed aan doen zich 
af te vragen wat de grenzen zijn van hun eigen vakgebied, temeer wanneer ze voortdurend bezig zijn andermans wetenschapsbeofening te begrenzen.

Een dergelijke negatieve reactie op ethiek (en recht) is bijzonder in teressant. Het is natuurlijk een vreemd verhaal. De auteur verwijt ethici de vooruitgang van de geneeskunde te belemmeren, maar het punt is juist dat niet duidelijk is wat precies telt als vooruitgang van medische kennis. Bovendien zal de commentator niet willen beweren dat toename van kennis van belang is, ongeacht de wijze waarop ze tot stand komt. Maar in éen opzicht heeft de schrijver volkomen gelijk. Hij heeft gelijk als hij de gevestigde relatie tussen ethiek en geneeskunde ter discussie stelt. Toch lijkt de schrijver tegelijkertijd zelf niet precies te weten waar hij zijn gelijk moet halen. Dat kan niet verbazen. Wat namelijk aan zijn betoog ten grondslag ligt is een filosofisch probleem : de verhouding tussen morele theorie en morele praktijk. Wanneer we dat probleem in het vizier nemen, blijkt de commentator zijn gramschap te richten op én bepaalde conceptie van ethiek en één specifieke medisch-ethische praktijk, die, hoewel ze heden ten dage overheersen, inderdaad aan kritiek onderhevig zijn. De kritiek is eigenlijk ook niet nieuw. De afgelopen decennia is ze in allerlei toonaarden herhaald, vooral door praktiserende medici, maar tot nu toe weinig serieus genomen.

Ik wil u laten zien welke rollen ethici momenteel spelen in de context van gezondheidszorg. Daardoor wordt duidelijk welk een gedifferentieerd geheel van medisch-ethische praktijken er feitelijk bestaat. Het kan nog veel erger worden dan de kriticus nu al waarneemt, maar het kan ook anders. Deze rede is ook een pleidooi voor een ander soort medisch-ethische praktijk dan momenteel gangbaar is.

\section{HET SCHOUWTONEEL DER ETHICI}

Laten we de kritiek op de hedendaagse medische ethiek serieus nemen, en wel als aansporing tot reflectie op ethiek zelf. Is medische ethiek momenteel op de goede weg? Beginpunt van zo'n evaluatie vormt de constatering dat ethici allesbehalve een eenheidsproduct vormen. Ze zijn er in velerlei soorten en met uiteenlopende signatuur. Er zijn verschillen in opleiding (theologisch of filosofisch), in opvatting (bijvoorbeeld Aristotelisch, Kantiaans of utilistisch), in levensbeschouwelijke oriëntatie (bijwoor " beeld katholiek, protestants of niet-religieus) en in leerstelligheid (van liberaal tot behoudend). 
Maar er zijn ook verschillen, en daar gaat het me nu om, in de manier waarop ethici hun vak beoefenen en in de wijze waarop ze aan hun discipline gestalte geven. Dat is het beste te illustreren door voor u hier cen aantal beoefenaars van medische ethiek het toneel te laten passeren. Ik doe dat uiteraard in figuurlijke zin : in de vorm van stereotypen omdat het niet gaat om het identificeren van ethici maar om het herkennen van verschillende typen van medisch-ethische praktijken.

De eerste ethicus die ik aan u will voorstellen, zullen we ethicus $A$ noemen. Hij heeft een gedegen opleiding in de theologie en filosofie achter de rug en beschikt over een brede kennis van normatieve theorien en tradities. Al enige tijd heeft hij een universitaire aanstelling. Vanuit een kleine vakgroep verzorgt hij een aantal uren onderwijs in het preklinisch medisch curriculum; erg omvangrijk is die onderwijstaak niet.

Door zijn lidmaatschap van de Societas Ethica onderhoudthijcontacten met buitenlandse collegae. Gespecialiseerde tijdschriftenzoals The Joumal of Medical Ethics en Bioethics volgt hij nauwlettend. Aan wetenschappelijk onderzock komt hij evenwel minder vaak toe dan hij zou willen. Dat komt omdat zijn agenda voor een belangrijk deel bepaald wordt door anderen. Het grootste deel van zijn werktijd besteedt A namelijk aan dienstverlening. Binnen zijn eigen instelling is hij lid van een aantal commissies, zoals de toetsingscommissie die bijna wekelijks bijeenkomt om onderzoekswoorstelJen op hun morele toelaatbaarheid te beoordelen. Daarnaast is A op grond van zijn specifieke deskundigheid lid van een aantal nationale adviescolleges en daardoor betrokken bij het opstellen van rapporten, aanbevelingen en beleidsdocumenten. Verreweg de meeste tijd is A kwijt doordat er blijkbaareenonverzadigbaremaatschappelijkebehoeftebestaataanethisch commentaar op medische ontwikkelingen. Telkens zijn er nieuwe voorvallen die belicht worden in de me dia en daarbij is de ethicus een welkome woordvoerder. Als A zou willen, kan hij bijna elke dag wel ergens in den lande een voordracht of bijdrage verzorgen.

De activiteiten van ethicus $B$ zijn voor een aanzienlijk deel van andere aard. Hij is nog maar sinds kort werkzaam in het academisch ziekenhuis. Onlangs was in een medisch vakblad een advertentie verschenen voor cen ethisch consulent; daarin lag de nadruk op klinische ervaring, contactuele eigenschappen en een pragmatische instelling. Omdat B zowel medicijnen als filosofie had gestudeerd, leek deze baan cen kolfje naar zijn hand. $N_{u}$ is hij gestationeerd bij de Sectie voor Klinische Ethick. Hij heeft een eigen kamer in het ziekenhuis. Weinig onderscheidt hem van een klinicus. Hij draagt een witte jas met zijn naam erop gestikt, heeft een pieper voor dringende gevallen en loopt mee met zaalvisites. Als zich een moreel probleem 
voordoet, wordt hij in consult geroepen. Hij bekijkt dan zelf de patiènt, spreekt zonodig met andere hulpverleners en met de familie, leest de status door en schrijft zijn bevindingen en aanbevelingen daarin neer. In de zak van zjjn witte jas zit een handboekje woor klinische ethick dat hij zonodig raadpleegt. Tijdens patiëntenbesprekingen levert $B$ meestal een actieve bijdrage. Veel van zijn tijd wordt besteed aan onderwijsactiviteiten; daarbij gaat hij vrijwel altijd uit van casuistick. Regelmatig organiseert B "praatjes" over bij voorbeeld informed consent of criteria woor het beëindigen van een behandeling. Artikelen schrijft hij het liefst samen met klinische collegae, bij woorkeur in de vorm van klinische lessen of casusbesprekingen. Hij houdt bij wat er verschijnt in tijdschriften als Pediatrics, Obstetrics \& Gynecology en Archives of Intemal Medicine. Sinds kort zijn er ook eigen tijdschriften voor klinische ethiek. Uiteraard is B lid van de Society for Bioethics Consultation. De status van ethisch consulenten is immers nog niet goed geregeld. B wijst er onder andere op dat er afspraken moeten komen voor de vergoeding van diens consulten. Daar staat natuurlijk tegenover dat ook de kwestie van de bevoegdheden van klinisch ethici opgelost moet worden. Een voorstel voor een specifieke ethische beroepscode is all in de maak.

Ethicus $C$ is een betrekkelijk zeldzame verschijning. Zijn belangstelling gaat vooral uit naar onderzoek. Daartoe pendelt hij woortdurend heen en weer tussen kliniek en universitaire afdeling. Zijn opleiding is een amalgaam van fillosofie, geneeskunde en sociale wetenschappen. Niet tevreden met de overwegend normatieve benadering van zijn collegae A en B wil hij allereerst onderzoeken hoe regels en normen in de praktijk van de gezondheidszorg feitelijk functioneren. Daarbij stelt hij zich op als een cultureel antropoloog die nu eens niet op een ver continent de binnenlanden intrekt op zoek naar vreemde stammen, maar die de gewoonten en rituclen van een belangrijke beroepsgroep in de eigen samenleving wil bestuderen. Net als ethicus $\mathrm{B}$ loopt hij mee in de kliniek, ditmaal niet om beschikbaar te zijn als moreel consulent maar om via participerende observatie zicht te krijgen op de diwerse manieren waarop morele problemen worden geidentificeerd, besproken en behandeld. Hij veronderstelt dat dit niet in alle medische contexten op dezelfde wijze geschiedt. Zo zal de morele ervaring van chirurgen verschillen van die van internisten; hun relatie met patinten heeft immers een typerend doel, hun competentie berust op bepaalde handelwijzen en hun praktijk heeft een specifieke organisatie. De morele ervaring van patiënten of verpleegkundigen in een dergelijke context kan weer anders zijn. Ethicus $C$ gaat het er om inzicht te krijgen in dit soort verschillen in morele ervaring. Naast veldwerk put hij daartoe uit nogal uiteen- 
lopende theorctische bronnen: bij woorbeeld sociologische literatuur over professionaliseringsprocessen, antropologische studies over ziekte en gezondheid, historisch onderzock naar de ontwikkeling van therapien, diagnostische procedures of afzonderlijke specialismen, en filosofische beschouwingen over de groei van medische kennis. Uiteraard houdt $\mathrm{C}$ de gangbare ethische literatuur bij, maar tevens heeft hij een speciale voorkeur voor tijdschriften als Social Science \& Medicine, Sociology of Health \& Ilness en Medical Anthropology Quarterly. Ethicus C heeft tot op heden nog niet voldoende medestanders gevonden om een aparte vereniging op te richten.

Tot zover deze revue van ethici. Wat hierdoor geillustreerd wordt, is de heterogeniteit wan medisch-ethische praktijken. Er zijn duidelijkwerschillende manieren om ethiek in de gezondheidzorg te beofenen. Verschil in ethische benadering komt dus niet uitsluitend voort uit variërende theoretische uitgangspunten of levensbeschouwelijke opvattingen, maar heeft evenzeer te maken met een meer basale differentiatie: namelijk de wijze waarop ethick in de gezondheidszorg operationeel wordt gemaakt.

\section{MEDISCH-ETHISCHE PRAKTIJKEN}

De drie typen van ethici zijn vertegenwoordigers van drie verschillende medisch-ethische praktijken. Die praktijken wil ik nu met elkaar vergelijken:

\section{Toegepaste ethiek}

Ethicus A is een typische vertegenwoordiger van toegepaste ethiek. Vanaf het eind van de zestiger jaren vat medische ethiek zichzelf op als "applied ethics", toegepaste ethiek. In een bekende definitie wordt dit als volgt uitgedrukt: medische ethiek is de toepassing van algemene ethische theorieen, principes en regels op problemen van therapie, zorgverlening en medisch-biologischonderzoek.

De conceptie van et hiek zoals in een dergelijke delinitie verwoord, bevat een vijftal samenhangende veronderstellingen:

a) Ethiek is toepassing van ethische theorie;

b) Een corpus van ethische theorieèn ligt klaar om toegepast te worden op praktische problemen;

() 
Ethici beschikken over een specifieke expertise bij het toepassen van ethische theorieèn, terwijl niet-ethici de problemen aanreiken waarop de theorieën worden toegepast;

d) Medische ethiek is niets anders dan algemene ethiek toegepast op geneeskunde;

e) Doel van medische ethiek is het verschaffen van op algemene ethische theorieën gegronde adviezen voor het medisch-praktisch handelen. ${ }^{12}$

Opelk van deze veronderstellingen wordt de laatste jaren uitgebreide kritiek geleverd. Het zou te ver voeren deze kritiek hier uitgebreid te bespreken. Twee conclusies springen echter in het oog.

1. Door ervan uit gaan dat ethiek toepassing is van theorieën heeft toegepaste ethiek voor zichzelf een specifieke expertise geclaimd. Daardoor is een wijziging in de status van medische ethiek mogelijk geworden. Een beroep op specifieke ethische competentie maakt medische thiek los uit haar verankering in de medische professie en verplaatst haar naar het domein van een nieuwe professie. Door ethiek op te vatten als toegepaste theorie heeft medische ethiek zich als aparte discipline kunnen profileren.

2. Anderzijds heeft deze professionalisering van medische ethiek een prijs gehad. Het ging ten koste van een sterk ingeperkte conceptie van ethiek. Theoretische inzichten van de algemene ethiek worden toegepast om praktische en concrete dilemma's op geneeskundig terrein te ontleden en op te lossen. Dat leidt ertoe dat ethiek gezien wordt als een handige vorm van management voor een bepaald soort problemen; ethiek als morcle technologie. Moeilijke keuzen worden plotseling gemakkelijk. De pijn, de onzekerheid en de ambiguiteit van moeilijke beslissingen worden omzeild. Ethiek wordt gereduceerd tot theorie en toepassing.

\section{Klinische ethiek}

Ethicus B is een typische vertegenwoordiger van een nieuwe conceptic van ethiek die sinds het eind van de zeventiger jaren, vooral in Noord-Amerika, sterk aan invloed heeft gewonnen. Deze conceptie wordt "klinische ethick" genoemd omdat ze beter aansluit bij praktische ervaringen in de dagelijkse context van gezondheidszorg.

Op drie verschillende wijzen wordt de toegenomen belangstelling voor klinische ethiek zichtbaar: 
1. Allereerst in het medischethisch onderwijs. In 1980 had meer dan $90 \%$ van de Amerikaanse medische opleidingen een onderwijsprogramma in de medische ethiek, tegen $8 \%$ tien jaar daarvoor. ${ }^{13}$ Aanvankelijk is dat onderwijs vooral geconcentreend in de preklinische fase, in de tachtiger jaren verschuift het accent naar de klinische fase. Ethiek-onderwijs wordt geintegreerd in de dagelijkse routine van de gezondheidszorg. Casus eerder dan theorieën vormen het uitgangspunt.

Vergeleken bij de situatie in de Verenigde Staten makt het ethiek-onderwijs in Europese landen een povere indruk. In ons land bij woorbeeld is de ontwikkeling ervan traag en moeizaam geweest. ${ }^{14}$ Nog altijd hebben niet alle medische faculteiten enigerlei vorm van ethiek-onderwijs; en slechts in enkele faculteiten strekt dat onderwijs zich uit tot de klinische fase.

2. Een sterke gerichtheid op de praktische context komt tot uiting in ontstaan en functioneren van medisch-ethische commissies. Ik bedoel hier niet de toetsingscommissies voor medische experimenten. In de Verenigde Staten had in 1981 ongeveer $1 \%$ van alle gezondheidszorginstellingen een dergelijke commissie; in 1984 was dat opgelopen tot $50 \%$ terwijl vorig jaar naar schatting een percentage van 70 werd bereikt. ${ }^{16}$ Ook in ons land heeft zich, zij het met enige vertraging, een dergelijke toename van medischethische commissies voorgedaan. Bij een peiling door de Nationale Ziekenhuisraad in september 1988 bleken 220 instellingen te beschikken over een voorziening voor thet afwegen van medisch-ethische vraagstukken (tegen 56 instellingen in 1986). ${ }^{17}$ De situatie is echter gecompliceerder, aangezien in de meerderheid van de instellingen de voorziening tevens fungeert als toetsingscommissie voor experimenten met mensen.

Het vrij plotseling ontstaan wan medisch-ethische commissies vormt een belangrijk sociaal fenomeen. Naar schatting zijn bijna 40,000 werkers uit de Amerikaanse gezondheidszorg in dit soort commissies actief. Hiervar is een op de drie medicus; ethici zijn het minst vertegenwoordigd. ${ }^{18}$ ook in ons land moet het om zeker 2000 mensen gaan die lid zijn van zo'n commissie. Maar wat zijn de verwachtingen van de leden? Wat bezielt hen? Hoe functioneren dergelijke commissies in de praktijk? We weten er nog betrekkelijk weinig van.

3. De meeste recente ontwikkeling is het ontstaan van klinisch-ethische consulfatiediensten. Het universiteitsziekenhuis van Chicago bij voorbeeld beschikt sinds 1986 over een ethische consultatiedienst waaraan zes artsen 
verbonden zijn. ${ }^{19}$ In Nederland is een dergelijke rol van whisch consulent niet geinstitutionaliseerd, maar dat kan met de snelle groei van het aantal commissies wel eens veranderen. Naar mijn mening is het niet gewenst dat klimische ethiek zich op deze manier in ons land manifesteert. Klinische ethiek is ontwikkeld vanuit kritiek op toegepaste ethiek. Heel bewust wordt gepoogd een nieuwe aanpak van de medische ethiek te ontwikkelen. $\mathrm{Bij}$ die poging wordt uitgegaan van een doordenking van wat kenmerkend is voor geneeskunde. Wat maakt geneeskunde tot een bijzonder vak? Een atntal elementen uit het zelf-begrip van geneeskunde wordt dan naar voren gehaald: de bijzondere aard van de arts-patiënt relatie, de asymmetrie van hulpverlening, het autonomieverlies door ziekte, de intrinsieke onzeker heid van medisch besluitworming. Theoretisch een interessante poging maar uit de wijze waarop klinische ethiek wordt beofend, blijkt niet dat er sprake is van een alternatieve conceptie van ethick, maar veeleer van een nieuw terrein waarop toegepaste ethiek zich kam ontplooien. Er is geen andere conceptie, alleen een andere context. Zodra de ethiek-consulent zich als nieuwe figuur aan het ziekbed aandient, worden er twee mechanismen op gang gebracht. Allereerst gaat hij zijn eigen rol scherper definiëren: Hij claim tbepaalde verantwoordelijkheden, hij wil een witte jas met een pieper, stelt eisen met betrekking tot de vergoeding van zijn consulten, wil zijn expertise erkend zien en streeft naar een eigen beroepscode. ${ }^{20}$ Daarnaast wordt behandelend artsen ontraden om zelf ethische aspecten in hun handelen aan de orde te stellen. Dat is immers specialistenwerk.

\section{Een andere mogelijkheid?}

Het wordt tijd de balans op te maken. Uit kritiek op toegepaste ethiek is zich een nieuwe medisch-ethische praktijk gaan ontwikkelen. Toegepaste ethiek met haar nadruk op theorie, methodische deductie en abstractie zou te ver af staan van de medische werkelijkheid en bovendien een vertekend beeld van ethiek overbrengen. Door ethiek te heroriënteren op de klinische realliteit van individuele patiëntenzorg is de afstand lussen ethick en prakische geneeskunde inderdaad overbrugd. Maar daarmee is weinig opgelost. In de praktijk wordt nog altijd gewerkt volgens het model van toegepaste ethiek, zij het nu uitdrukkelijk in een klinische context. Theoretisch is $\mathrm{kli}$ nische ethiek ontwikkeld vanuit de opvatling dat technische en normatieve aspecten van het medisch handelen nauw verweven zijn; in de prakijk leidi dat er evenwel niet toe dat medici morele aspecten van hun handelen expliciet aan de orde stellen; de behandeling van die aspecten wordt gedelegeerd aan een nieuwe functionaris. Ook de rol van de ethicus verandert daarmee. Is hij in de conceptie van toegepaste ethick vertegenwoordiger 
van de patiënt, nu is hij allereerst vertegenwoordiger van de arts. In die laatste functie loopt hij het risico zo nauw geallieerd te zijn met (collega-) medici dat hij geen ruimte meer beeft voor kritische distantie.

De vraag is of er een weg bestaat tussen dissidentie en alliantie. Is medische ethiek ofwel een onderdeel van de algemene thiek ofwel een specifieke beroepsethiek? Staan we, met andere woorden, voor de lastige keuze tussen toegepaste ethick als obstakel en klinische ethiek als smeermiddel voor medische vooruitgang?

Met de formulering van deze vragen geef ik al aan dat een andere conceptie van medische ethiek mogelijk is.

Twee elementen uit de voorafgaande beschouwing zijn hiervoor belangrijk. Op de cerste plaats worden de theoretische uitgangspunten van de conceptie van klinische ethick serieus genomen. Kort gezegd: karakteristiek voor medisch handelen is dat technische en normatieve aspecten daarin nauw met elkaar verweven zijn. Dat betekent dat geneeskunde gekenmerkt wordt door een interne moraliteit en dat ethiek een reflexieve functie van genceskundezelf is. Omgeneeskunde professioneel te beoefenen is ethische reflectie door de beroepsbeoefenaar zelf onontkoombaar. Er is dus wel degelijk een specifieke beroepsethiek, al fungeert die niet in het luchtledige. Van deze veronderstelling gaan we uit zolang tenminste geneeskunde zich zelf niet begrijpt als pure dienstverlening, maar als een bijzonder vak dat speciale eisen, ook morele, met zich meebrengt.

Op de tweede plaats valt op hoe in de concepties van toegepaste en klinische ethiek de functie van ethiek vooral bestaat in het normeren van handelingsopties; soms heel voorzichtig, als het verhelderen en analyseren van normen, soms meer directief, als het voorstellen en prefereren van specifieke normen. In al deze gevallen stelt de ethicus zich op als iemand die suggereert, voorstelt of weet wat er het beste gedaan kan worden. De vraag is of de rol van de ethicus niet op meer bescheiden wijze kan worden ingevuld: minder normerend, meer interpreterend.

\section{Hermeneutische ethiek}

Een antwoord op deze vraag wordt ons aangereikt in het werk van de Amerikanse medisch socioloog Charles Bosk. ${ }^{21}$ Doorparticiperendeobservatie heeft Bosk nagegaan hoe normen van competent klinisch handelen geconstrueerd en geleerd worden tijdens de opleiding tot chirurg. In de praktijk bleek een fundamenteel onderscheid te functioneren tussen ver- 
wijtbare en niet-werwijtbare fouten. Tekort schieten in competent handelen kan namelijk twee verschillende dingen betekenen:

a) Een tekort schieten in het toepassen van het theoretisch kennisbestand of van de vaardigheden waarop het professioneel chirurgisch handelen berust. In dit geval is sprake van een beoordelingsfout of wan een technische fout.

b) Een tekort schieten in het nakomen van de impliciete gedragscode waarop het professionele handelen berust. Dan is sprake van een normatieve fout.

Deze laatste fout blijkt in de praktijk altijd zwaarderte worden aangerekend dan de beide andere. Bij een technische fout heeft de vaardigheid van een beroepsbeoefenaar gefaald; er is geen reden te twijfelen aan diens goede bedoelingen, zolang er tenminste sprake is van snelle rapportage en het niet vaak herhalen van dezelfde fout.

$\mathrm{Bij}$ een beoordelingsfout is een onjuiste behandeling gekozen uit gebrek aan klinische ervaring. Dit is een teken van cognitieve incompetentie; het wijst op de noodzaak van verder onderricht, tenminste zolang degene die de fout beging bereidheid wertoont tot zelf-kritiek.

Bij een normatieve fout ligt de zaak anders. De beroepsbeoefenaar heeft dan niet woldaan aan wat zijn professionele rol verlangt; hij heeft bij voorbeeld niet voldoende opening van zaken gegeven aan zijn opleiders, heeft geen goede werkrelatie met de verpleging of is niet in staat medewerking te verkrijgen van de patient of diens familie. Een normatieve fout is een indicator voor gebrek aan eerlijkheid en verantwoordelijkheid. Daardoor is ze een signaal dat het belang van de patiënt niet op de eerste plaats komt.

Een beoordelingsfout en een technische fout zeggen iets over het kennis en trainingsniveau van een chirurg; ze signaleren een deviatie binnen een rol. Een normatieve fout daarentegen zegt iets over de chirurg zelf; ze signaleert een verkeerde rol, $_{\text {, }}$ liever gezegd, ze geeft te kennen dat iemand uit zijn rol is gevallen.

Bosk concludeert dan ook dat het onjuist is dat artsen niet bezig zijn met ethiek. De opleiding van chirurgen is boven alles een morelo vorming. Maar deze morele vorming is meestal zo verweven met hel aanleren van technische en cognitieve competenties dat ze niet expliciet benoemd of herkend wordt als ethiek. Toch vormen voor de bestudeerde professionele gemeenschap morele maatstaven het organiserend principe. Morele fouten verstoren het delicate weefsel van relaties tussen beroepsgenoten onderling; ze tonen namelijk dat persoonlijke overwegingen de overhand hebben op bescherming van het belang van de patiënt. De bijzondere aard van de 
arts-patient relatie werklaart dus uiteindelijk waarom het normatieve functioneren van een beroepsbeoefenaar zoveel zwaarder wordt gewogen dan zijn technisch-cognitieve competentie.

Het onderzoek van Bosk maakt twee zaken duidelijk. Op de eerste plaats lat het zien dat medisch handelen zichzelf begrijpt als moreel verantwoord handelen. Dat betekent dat in de dagelijkse praktujk morele overwegingen, zij het meestal impliciel, een constitutieve rol spelen woor die praktijk. Inherent alan medisch werk is dat het technische en het morele voortdurend aan elkaar gekoppeld zijn.

Op de tweede plaats geeft Bosk aan wat de rol wan de ethicus kan zijn; hij zal allereerst moeten interpreteren wat er in de praktijk gebeurt. Wat wordt in een bepaalde praktijkcontext als morele ervaring beschouwd? Hoe worden het morele en het technische gekoppeld en ontkoppeld? Hoe kan de normatieve dimensie van het professioneel handelen worden opengelegd, openbaar gemaakt voor relatieve buitenstaanders?

In dit soort vragen komt een nieuwe conceptie van ethiek naar voren: ethiek als hermeneutiek van de morele ervaring.

Wat moreel is, weten wij alleen uit onze ervaring. De morele erwaring, aldus Van Tongeren, is de manier waarop wij ons zelf en/in de wereld in morele termen verstaan. ${ }^{22}$ Ethiek is dan de kunst en theorie van het verstaan en uitleggen van de morele ervaring. Onze morele ervaring kan minder helder geworden zijn of niet goed meer verstaan worden, zodat nadere uitleg geboden is. De kunst van dat uitleggen en de theorie waarin die kunst wordt uitgelegd is de hermeneutiek, oorspronkelijk onder andere gebruikt in de theologie als uitleg van de betekenis van gezaghebbende teksten.

\section{EEN ANDERE MEDISCH-ETHISCHE PRAKTIJK}

Wat zijn nu de consequenties van een dergelijke hermeneutische conceptie voor de medische ethiek?

\section{Bescheiden opstelling van de ethicus}

Op de eersite plaats heeft een hermeneutische conceptie gevolgen voor de dienstverlenende rol van de medisch-ethicus. Voor beoefening van ethiek is betrokkenheid bij medisch werk essentieel. Morele ervaring moet worden gedeeld om uit te leggen wat zij in gegeven situaties allemaal te verstaan geeft. Daaruit moeten we niet afleiden dat alleen artsen eigenlijk ethici kunnen zijn, want de morele momenten van hun ervaring blijven meestal 
impliciet. Het morele moet geẻxpliciteerd worden, dat is een taak voor ethici. Maar om die taak goed te vervullen, moeten morele ervaringen zovel als mogelijk is worden gedeeld, trouwens niet alleen die van artsen, maar ook die van patiënten.

De consequentie hiervan is dat de rol van de medisch-ethicus meer bescheiden wordt ingevuld dan tot nu toe het geval is. Hij beseft dat iedere witleg perspectivistisch en woorlopig is. Daarom presenteert hij zich niet als jemand die antwoorden op zak heeft, een mening paraat over actuele problemen. Want hij weet dat zo'n uitspraak in feite misbruikt zal worden als ethische legitimering wan gangbare handelwijzen.

Langs deze weg zal misschien een ander type ethiekbeoefening gestalte krijgen: een ethiekbeoefening die een beroep doet op sensibiliteit, inlevingsen verbeeldingsvermogen, die laat zien welke fundamentele waarden eigenlijk achter regels en principes verborgen liggen, die een bepaalde grondhouding poogt te ontdekken of verrijken en die appelleert aan een ideaal van samen-leven. ${ }^{23}$

\section{Ander type onderzoek}

Een tweede consequentie is dat een ander type onderzoek noodzakelijk is. In feite is morele ervaring zelf empirie. Dat betekent dat, net als in de recente wetenschapsfilosofie, ook in de ethiek een empirische wending gewenst is. De stricte scheiding tussen descriptieve en normatieve ethiek moet worden opgeheven ten gunste van een meer adequate verkenning van het morele in de geneeskunde. De onderzoekingen van Bosk vormen een goed voorbeeld van zo'n aanpak. Bijdragen vanuit de sociale wetenschappen kunnen het ethisch discours verrijken. ${ }^{24}$ Het valt dan ook alleszins toe te juichen dat nu in ons land gestart wordt met een empirisch onderzoek naar de praktijk van euthanasie. Alleen in het perspectief van toegepaste ethiek is dat een bedreiging omdat gevreest wordt voor universaliserende regelgeving. Vanuit hermeneutisch perspectief kan zo'n onderzoek bijdragen aan het expliciteren van morele ervaring, en waarom zouden wij die crvaring niet willen uitleggen en willen begrijpen? Daarmee lijkt mij de medische cthick meer gebaat dan met een woortgaand publiek gescherm met regels en principes. Ook voor de geneeskunde zelf lijkt me dï de meest verkieslijke weg. Als praktijken berusten op valide morele ervaring, dan valt cr niets te verbergen; het specifieke karakter van die ervaring kan worden aangetoond. Maar ook als de morele dimensie in die praktijken zou ontbreken, is er geen reden dat verborgen te houden; integendeel, er zou des te meer aanleiding voor de medische professie zijn dat te openbaren en te corrigeren, zolang ze tenminste zichzelf niet wenst te reduceren tot pure dienstver- 
lening. Alleen in dat laatste geval zijn empirisch onderzoek en ingewikkelde thische discussies overbodig; wat er dan moet gebeuren is het maken van een juridische regeling met nacontrole door een soort keuringsdienst van waren. Dat zal betrekkelijk eenvoudig zijn want in juridisch opzicht is de consument tot nu toe beter beschermd dan de patiënt.

Ook een tweede type onderzoek is node gewenst, namelijk cross-cultureel onderzoek. Met name in de Amerikaanse medische ethiek ontwaakt het besef van inbedding in een specifieke culturele matrix. Duidelijk is dat bij voorbeeld in de nadruk op autonomie en individuele rechten en in de beperkte wisie op solidariteit. Door er steevast van uit te gaan dat ethiek een transculturele onderneming is, wordt de "Amerikaansheid" van medische thiek tot nu toe nauwelijks herkend.

Voor de medische ethiek betekent het miskennen van de context een verarming. De historische, sociale en culturele particulariteit waaruit de uitleg en interpretatie wan morele ervaring voortkomen, wordt zodoende geen rechtgedaan. Meer aandacht voor comparatieve ethiek is daarom gewenst. Ook in eigen land bestaan uiteenlopende morele praktijken en tradities, meestal met een verschillende levensbeschouwelijke achtergrond. Het eigene van die tradities wordt door de bekonmernis om universeel toepasbare regels en principes niet hoog aangeslagen. Vanuit de gedachte dat er een soort "moreel Esperanto" bestaat en met het idee dat het de ethiek bij] uitstek te doen is om de constructie van universaliseerbare standpunten, worden alle verschillen gehomogeniseerd. ${ }^{25}$ Toch blijft er in de praktijk grote variatie en heterogeniteit bestaan, zoals bij voorbeeld Bergkamp niet lang geleden aantoonde in een onderzoek bij toetsingscommissies voor klinische experimenten. ${ }^{26}$ Vanuit een juridisch oogpunt van uniforme regelgeving is eendergelijkevariatie ingehanteerdenormengeenstimulerendeheterogeniteit maar ongewenste inconsistentie. Maar waarom zou het medisch-ethisch oordeel met het juridische samenvallen? Per slot van rekening blijken er ook in andere sectoren van de geneeskunde veel meer variatie en diversiteit te bestaan dan meestal wordt gedacht. Zo werd begin worig jaar in de British Medical Joumal een uitgebreide discussie gevoerd over de vraag of constitutionele hypotensie wel bestaat. ${ }^{27} \mathrm{Bij}$ onze oosterburen is dat een welomschreven ziektebeeld waarwoor tientallen soorten geregistreerde geneesmiddelen beschikbaar zijn. Maar in de Angelsaksische wereld komt een dergelijke zickte in de medische handboeken niet voor; het wijst integendecl op een betere levensverwachting dan een normale bloeddruk en het kwalificeert dan ook voor een lagere levensverzekeringspremie.

Dergelijke verschillen hoeven ons niet te verbazen. Wat geneeskunde is, hoe geneeskunde gedemarceerd wordt, wat ziek is en wat gezond, dat 
alles hangt af van de cultuur en daarin vigerende mens-en wereldbeelden. Als de normen die aan deze cultuur-bepalde beelden worden ontleend zulke uiteenlopende gevolgen hebben, waarom verontrust ons dan de variatic aan de bron: de heterogeniteit van morele ervaring en waardering. Cultuur bestaatprimairdoorverscheidenheid. Ook ethiekvindtdaarin haarbestaansgrond.

\section{De kritische functie van de ethicus}

Een laatste consequentie van een hermeneutische conceptie van ethiek betreft de kritisch functie van de medisch ethicus.

We zagen eerder hoe in de praktijk van de patiëntenzorg technische en normatieve aspecten van medisch handelen voortdurend aan elkaar gekoppeld zijn. We zagen ook hoe die koppeling voortwloeit uit het zelfbeeld van de geneeskunde als een bijzondere professie. Kern van dat zelfbeeld vormt een relatieconcept. Een beroep doen op medische hulp kan niet uitsluitend gekarakteriseerd worden alseen transactie of contractussen twee partijen. Kenmerkend voor hulpverlening is een relationaliteit die voor het behandelings- en genezingsproces zelf van belang is. Vandaar de voortdurende aandacht in medische literatuur voor de arts-patiënt relatie, ook al wordt daar nu in veel minder idealist ische bewoordingen over gesproken dan in het verleden.

Als het geschetste zelfbegrip van geneeskunde nog altijd in de kern aanwezig is, wat betekent het dan voor de functie van de medisch ethicus? De professionalisering van medische ethiek en de dominante conceptie van toegepaste ethiek hebben immers een cruciale aanslag gepleegd op dit zelfbegrip. Ze hebben de medische ethiek, om zo te zeggen, onteigend. Daarom lijkt het erop, zoals de eerder besproken ethiek-kritiek laat zien, alsof geneeskunde haar identiteit alleen nog kan benadrukken door zich af te zetten tegen toegepaste medische ethiek.

Op de allereerste plaats zou medische ethick dus weer terug gebracht moeten worden naar waar ze thuis hoort: in het hart van gezondheidszorgpraktijken. In het bedrijven van geneeskunde zijn morele overwegingen noodzakelijk aan de orde, of ze nu zo genoemd worden of niet.

In het verlengde hiervan is het de functie van een ethicus om als een etnograaf deze morele erwaring van praktijken te bestuderen, uit te loggen, te interpreteren. Net als de klinische ethicus participeert hij in diverse gezondheidszorgpraktijken om morele ervaring te kunnen begrijpen van binnen uit. Maar anders dan de klinisch ethicus affilieert hij zich niet met Eén van de participanten. Net als de cultured antropoloog inleresseert hem verschil, onderscheid, vreendheid, het andere. Daarom wil hij zich niet 
identificeren met degene in wiens ervaring hij zich inleeft. Tegelijkertijd verschilt hij weer van de cultureel antropoloog doordat hij een kritisch perspectief wil ontwikkelen op de onderzochte praktijk. Als ethicus wil hij niet slechts allerle morele enclaves in kaart brengen. De vraag is hoe kritiek mogelijk is. Hoe kunnen we bestaande praktijken serieus nemen en tegelijkertijdeen kritisch perspectief eropontwikkelen? Dekritiek op toegepaste ethiek laat zien dat het antwoord niet bestaat in een poging ons boven onze situatie uit te tillen en een abstract standpunt in te nemen. Ethiek begint altijd op een bepaalde plaats; ze ontwikkelt zich vanuit een moreel discours dat al in gebruik is. Het enige alternatief dat ons rest is het zoeken naar prakt ische mogelijkheden voor dialoog, gesprek, communicatie tussen morele praktijken en tradities. De kritische functie van de medisch ethicus bestaat in dit geval in het openleggen wan de normatieve dimensie van gezondheidszorgpraktijken. Het interpreteren wan morele ervaring vereist altijd een gemeenschappelijkheid vereist, een samen-verstaan. Juist in het gesprek met anderen begrijpen we beter wat ons bezield; omgekeerd kunnen we alleen in gesprek andermans opvattingen verstaan. Dat verondersteit dat we in de ervaring elementen met elkaar delen. Als mensen niets gemeenschappelijks hebben, is verstaan van elkaars morele opvattingen uitgesloten.

Uitleg geeft dus inzicht en inzicht maakt duidelijk wat ons beweegt. Interpretatie geeft precies in gesprek met anderen vorm aan een praxis. Dilardoor krijgt ethiek normatieve betekenis. De ethicus zall ervoor moeten zorgen dat een dergelijk gemeenschappelijk beraad over morele ervaring tot stand komt.

\section{CONCLUSIE}

Dames en heren, ik heb laten zien hoe kritiek op ethiek aanleiding kan zijnt tot het onderkennen vanverschillende medisch-ethische praktijken. Medische ethiek kan anders worden beoefend dan we nu gewend zijn. Dat is de les die we kunnen leren van de theologische traditie, waarin hermeneutick vanouds zo'n belangrijke rol speelt. Veel pleit ervoor om medische thiek anders te gaan beoefenen. Dat betekent wel dat artsen en patiënten hun morele ervaring serieus nemen. $\mathrm{Zij}$ zijn het eigenlijk die medische ethiek gestalte moeten geven.

Ik dank u voor uw aandacht. 


\section{NOTEN}

1. RA. McCormick: The Critical Calling. Reflections on moral dilemunas since Vatican II. Georgetown University Press, Washington, D.C., 1989. Zie hiervoor ook van detelfde auteur. Pluralism within the Church. In: E.D. Pellegrino, J.P. Langan d. J. Harvey (eds.): CatholicPerspectives on Medical Morals. Foundational Issues. Kluwer Acad. Publ ${ }_{*}$ Dordrecht, 1989, p. 147-167.

2. Zie hiervoor onder andere B. Schüller: Philosophical Foundations of Catholic Medical Morals. In: ED. Pellegrimo et all. (eds.): O.c., 1989, p. 61-78.

3. Zie R.A. McCormick: O.c., Hfo. 2, p. 25 e.v.

4. Crr.J.C. Harvey: A Brief History of Medical Ethies from the Roman Catholic Perspective: Comments om the Essays of Fuchs, Demmer, Cahill and Hellwig Im: E.D. Pellegrino et al. (eds.): O.c. p. $129-144$

5. Een overzicht voor Nederland geeft A.Th.L.M. Mertens: Historie van katholieke artsen en hun ethische opvattingen. In: Bernardus kardinaal Alfrink e a. : De identiteit van katholiekewetenschapsmensen. Amboboeken, Baarn, 1980, p. 114-140.

6. Congregation for the Doctrine of the Faith: Instruction on Respect for Human Life, in its Origin and on the Dignity of Procreation. Replies to certain Questions of the Day. Vatican Cily, 1987.

7. Zie onder meer H. ten Have: Donum Vitae, bezien naar zijn tekontorningen. In: Katholieke Vereniging van Ziekeninrichtingen: Vruchtbaarheid en voortplanting: beschouwingen rondom het Romeinsedocunnent DonumVitae, 1988, p. 49-69. Zie ook L.S. Cahill: Moral traditions, ethicallanguage, and reproductive technologies. The Journallof Medicine and Philosophy 14, 1989 , p. 497-522.

8. A.G.M. van Melsen: Natumrwetensehapen Ethiek. Een bezinningop het verband tussen natuur en zedelijkheid. Uitgeverij De Nederlandsche Boekhandel, Antwerpen, 1967; A.G.M. van Melsen: Natuurwetenschap en Natuur. Een inleiding in de natuurfilosofie. Ambo, Nijmegen/Baarn, 1983.

9. J.C. Harvey: Speculations regarding the Histony of Donum Vitac. The Journalof Medicine and Philosophy 14, 1989, p. $481-491$.

10. J.P. Vandenbroucke" Medische ethiek en gezondheidsrecht; hinderpalen voor de verdere toename van kennis in de geneeskunde? Ned Tijdschr Geneeskd 134,1990, p. 5-6.

11. Deze definitie wordt gegeven in T.L. Beauchamp \& J.F. Childress: Principles of Bio. medical Ethics. Oxford University Press, New York/Oxford, 1983 (2e dr.), p. ix-x.

12. Zie hiervoor: $\mathrm{H}$. ten Have \& $\mathbf{G}$. Kinsma: Changing Conceptions of Medical Ethics. In: U.J. Jensen and G. Mooney: Chamging Values in Medical and Health Care Decision Making. J. Wiley, Chichester, 1990, p. 33-51;en ook: J.M. Brown: On applying ethics. In J.D.G. Evans (ed.): Moral Philosophy and Contemporary Problenus. Cambridge Uniwersity Press, Cambridge, 1987, p. 81-93.

13. Zie: H.A.M.J. ten Have G.K. Kimsma: Medisch-ethisch onderwijs in de Verenigde Staten en in Nederland. Ned Tijdschr Geneeskd 131, 1987, p. 1447-1449.

14. Een recent overzicht geeft P.J. Kuijjer: De plaals van de metamedica in de faculteit der geneeskunde. In: L.M. Schure et al. (red.): Een huisarts rwel-beschouwd. Wetenschappelijke Uitgeverij Bunge, Utrecht, 1989.

15. H.A.M.J.ten Have \& G.G.M. Essed: Ethiseh onderwijs in de klinische lasc. Ned Tijdschr Geneeskd 133, 1989, p. 687-689. 
16. Voor 1981 zie S. Y. Youngner et al. : A National Survey of Hospital Ethics Committees. In: Decidingto Forego Life-Sustaining Treatment. U.S. Government Printing Office, Washington, D.C., 1983, p. 443-449; Voor 1985 zie J.W. Ross el al. Handbook of Hospital Ethics Committes. American Hospital Publ. Inc, Chicago, 1986, p. 7; Voor 1989 mondelinge mededeling van Thomasine Kushner (University of California at Berkeley), mei 1989 .

17. H.H. van der Kloot Meiflourg, K.M. Brouwer de Koning-Breulker en G.K Kimsma: De rol van de filosoof in medisch ethische commissies. I. Ontwikkellingen en mogelijkheden. Medish Contact 44, 1989 , p. $161925-1629$.

18. Deze gegevens zijn werkegen uilt onderzoek ower 1988 , verricht door Thomasine Kushner (mondelingetnededeling).

19. J. La Puma: Consultations in cinical ethics: Issues and Questions in 27 Cases. West J Med 146, 1987, p. 633-637. I. La Puma el al. : An Ethics Consultation Service in a Teaching Hospital. Utilization and Evaluation. JAMA260, 1988, p. 808-811.

20. Zieonder andere B. Fredman: Bringing Codes to Newcastle: Ethics for Clinical Ethicists. In: B. Hoffmaster, B. Freedman \& G. Fraser (eds.): Clinical Ethics. Theory and Practice. Humana Press, Clifton, New Jersey, 1989, p. 125-139.

21. CL. Bosk: Forgive and Remember. Managing Medical Failure University of Chicago Press, Chicago/London, 1979.

22. P. van Tongeren: Ethick en Praktijk. Filosofie \& Praktijk $9,1988^{2}$ p. 113-127.

23. Zie hierwoor P. Sporken: Exhiek: Appel aan het goede in de mens. Afscheidsrede, Rujksuniversiteit Limburg, Maastricht, 1988.

24. Een voorstel voor dergelijk onderzoek is onlangs gedlaan door $H$. Philupsen: Gezondheid zorg als project en bejegening. Waarden ten aanzien wan ziekte, gezondtheid en samenlewing Rujksuniversiteit Limburg, Maastricht, 1988.

25. De term "moreel Esperanto" en de daarmee verbonden problematiek worden geintroduceerd en besproken in het werk van J. Stowt: Ethics after Babel. The Languages of Morals and their Discontents. Beacon Press, Boston, 1988.

26. L. Bergkamp: Hetproefdiermens. Denormeringen reguleringvanmedische experimenten metmensen. Alphen aam den Rijn, Samson, 1988.

27. J.Pemberton: Does constitut ional hypotension exist? British Medical Journat 298, 1989 , p. 660-662. Zie voor daaropvolgende ingezonden brieven: Ibidem, p. 1031-2 en p. 1251 . Een beschrijwing van allerlei culturele verschillen in medische behandeling en medische kennis geeft L. Payer: Medicine and Culture: Varieties of Treatment in the United States, England, West Germany and France. Henry Holt and Co., New York. 